\title{
BILANGAN TERHUBUNG TOTAL PELANGI PADA GRAF GARIS DAN DOUBLE GRAF GARIS DARI GRAF SIKAT
}

\author{
Dorotea Rahmawati, Helmi, Fransiskus Fran
}

\begin{abstract}
INTISARI
Pewarnaan graf $G$ merupakan pemetaan himpunan titik di $G$ ke himpunan warna dengan titik yang bertetangga memiliki warna yang berbeda. Salah satu pengembangan dari pewarnaan graf yang sering dibahas adalah pewarnaan total pelangi. Misalkan $G=(V(G), E(G))$ adalah graf terhubung tak trivial. Pewarnaan total graf $G$ disebut terhubung total pelangi jika memiliki lintasan total pelangi antara setiap dua titik di G. Lintasan total pelangi merupakan lintasan dengan semua sisi dan titik internal pada lintasan tersebut memiliki warna yang berbeda. Bilangan terhubung total pelangi pada graf $G$ dinotasikan dengan $\operatorname{trc}(G)$ yaitu jumlah warna terkecil yang dibutuhkan untuk membuat graf $G$ menjadi terhubung total pelangi. Penelitian ini bertujuan untuk menentukan nilai $\operatorname{trc}(G)$ dimana $G$ adalah graf garis dari graf sikat dan double graf garis dari graf sikat. Graf sikat dinotasikan $B_{n}$ dengan $n \geq 2$ dan $n \in \mathbb{N}$ merupakan graf dengan $2 n$ titik dan $2 n-1$ sisi. Graf garis dari graf sikat $\left(L\left(B_{n}\right)\right)$ adalah graf dengan himpunan titik pada $L\left(B_{n}\right)$ merupakan himpunan sisi pada $B_{n}$. Double graf garis dari graf sikat $\left(D\left(L\left(B_{n}\right)\right)\right)$ merupakan graf yang terdiri dari dua graf $L\left(B_{n}\right)$ yang mempunyai lintasan yang sama. Berdasarkan penelitian ini diperoleh bilangan terhubung total pelangi pada graf garis dari graf sikat adalah $\operatorname{trc} L\left(B_{n}\right)=2 n-1$ dan double graf garis dari graf sikat adalah $\operatorname{trc} D\left(L\left(B_{n}\right)\right)=2 n+1$.
\end{abstract}

Kata kunci: pewarnaan total pelangi, terhubung total pelangi, lintasan total pelangi

\section{PENDAHULUAN}

Pewarnaan graf $G$ merupakan pemetaan himpunan titik di $G$ ke himpunan warna dengan titik yang bertetangga tidak memiliki warna yang sama. Pewarnaan graf berkembang menjadi pewarnaan pelangi. Misalkan $G$ adalah graf terhubung tak trivial dan didefinisikan pewarnaan $c: E(G) \rightarrow$ $\{1,2, \ldots, k\}, k \in \mathbb{N}$ pada sisi-sisi di $G$ dimana sisi yang bertetangga boleh memiliki warna yang sama. Suatu lintasan $u-v$ di $G$ adalah lintasan pelangi jika tidak ada dua sisi yang berwarna sama pada lintasan tersebut. Graf $G$ dikatakan terhubung pelangi jika $G$ memiliki sebuah lintasan pelangi $u-v$ untuk setiap dua titik $u$ dan $v$ di $G$. Dalam kasus ini pewarnaan $c$ disebut pewarnaan pelangi di $G$ [1].

Pewarnaan pelangi juga berkembang menjadi pewarnaan titik pelangi. Pewarnaan titik pada graf $G$ disebut terhubung titik pelangi (pewarnaan titik pelangi) jika setiap dua titik yang terhubung oleh sebuah lintasan dimana titik internal pada lintasan tersebut memiliki warna yang berbeda [2].

Seiring berjalannya waktu, pewarnaan pelangi juga berkembang lagi menjadi pewarnaan total pelangi. Pewarnaan total pelangi merupakan pewarnaan pada titik dan sisi pada graf $G$ sehingga setiap pasang titik pada graf $G$ mempunyai lintasan total pelangi. Topik yang sering dikaji dalam konsep pewarnaan total pelangi adalah bilangan terhubung total pelangi pada beberapa graf khusus, misalnya pada graf sikel, graf roda, dan graf lengkap bipartit [3]. Oleh karena itu, pada penelitian ini dianalisis bilangan terhubung total pelangi pada graf garis dan double graf garis dari graf sikat. Graf sikat dinotasikan $B_{n}$ dengan $n \geq 2$ dan $n \in \mathbb{N}$ dengan $2 n$ titik dan $2 n-1$ sisi merupakan graf yang dikonstruksi dari graf lintasan $P_{n}$ dan graf bintang $S_{n}$. Graf lintasan $P_{n}$ merupakan graf dengan $n$ titik dan hanya mempunyai 1 lintasan untuk setiap pasang titiknya. Sedangkan graf bintang $S_{n}$ merupakan graf dengan satu titik yang bertetangga dengan $n$ titik lainnya. Semua graf-graf tersebut merupakan graf sederhana terhubung dan tak berarah, termasuk graf garis dan double graf garis dari graf sikat. 
Langkah awal untuk menentukan bilangan terhubung total pelangi pada graf garis dan double graf garis dari graf sikat adalah membentuk graf garis dan double graf garis dari graf sikat. Setelah itu menentukan diameter dari masing-masing graf khusus, yang kemudian graf-graf ditentukan fungsi pewarnaan total pelangi $c$, dimana dari fungsi inilah diperoleh bilangan terhubung total pelangi, yaitu $\operatorname{trc}(G)$.

\section{BILANGAN TERHUBUNG TOTAL PELANGI}

Pada bagian ini dibahas mengenai bilangan terhubung total pelangi. Namun sebelumnya diberikan definisi diameter dan lintasan total pelangi suatu graf $G$.

Definisi 1 [4]. Diameter suatu graf $\boldsymbol{G}$ adalah jarak terbesar untuk setiap dua titik pada graf $\boldsymbol{G}$. Diameter graf $\boldsymbol{G}$ dinotasikan dengan $\operatorname{diam}(\boldsymbol{G})$.

Sebagai ilustrasi dari Definisi 1, diberikan graf $G_{1}$ seperti Gambar 1.

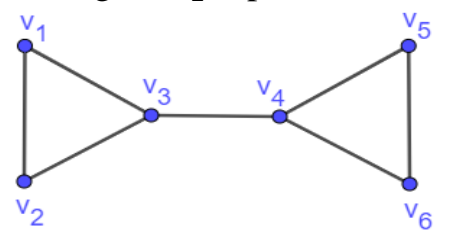

Gambar 1. Graf $G_{1}$

Berdasarkan Gambar 1, diperoleh bahwa jarak terbesar untuk setiap dua titik pada graf $G_{1}$ adalah 3, yaitu salah satunya dari titik $v_{1}$ ke $v_{5}$. Oleh karena itu, diam $\left(G_{1}\right)=3$. Selanjutnya diberikan definisi mengenai lintasan total pelangi pada Definisi 2 dan terhubung total pelangi pada Definisi 3.

Definisi 2 [5]. Misalkan $G$ graf terhubung dengan pewarnaan $c: V(G) \cup E(G) \rightarrow\{1,2, \ldots, k\}, k \in \mathbb{N}$. Sebuah lintasan $P$ di $G$ yang menghubungkan dua titik $u$ dan $v$ disebut lintasan total pelangi antara titik $u$ dan $v$ jika semua anggota di $V(P) \cup E(P)$, kecuali titik $u$ dan $v$, diberi warna yang berbeda oleh $c$.

Definisi 3 [5]. Pewarnaan total pada suatu graf $G$ merupakan terhubung total pelangi jika $G$ memiliki lintasan total pelangi antara setiap dua titik di $V(G)$. Jumlah warna minimal yang dibutuhkan sehingga $G$ bersifat terhubung total pelangi disebut bilangan terhubung total pelangi yang dinotasikan dengan $\operatorname{trc}(G)$.

Sebagai ilustrasi Definisi 2 dan Definisi 3, diberikan graf $G_{2}$ seperti Gambar 2.

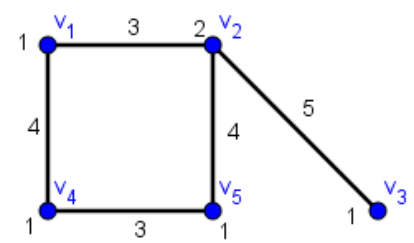

Gambar 2. Graf $G_{2}$

Berdasarkan Gambar 2, diperoleh setiap dua titik pada $G_{2}$ mempunyai lintasan total pelangi seperti yang disajikan pada Tabel 1 . Oleh karena itu, $G_{2}$ dikatakan terhubung total pelangi.

Tabel 1 Lintasan Total Pelangi pada Graf $\boldsymbol{G}_{\mathbf{2}}$

\begin{tabular}{|c|c|c|c|c|c|}
\hline \multicolumn{7}{|c|}{ Lintasan total pelangi } \\
\hline Titik & $v_{1}$ & $v_{2}$ & $v_{3}$ & $v_{4}$ & $v_{5}$ \\
\hline$v_{1}$ & - & $v_{1}, v_{2}$ & $v_{1}, v_{2}, v_{3}$ & $v_{1}, v_{4}$ & $v_{1}, v_{2}, v_{5}$ \\
\hline$v_{2}$ & $v_{1}, v_{2}$ & - & $v_{2}, v_{3}$ & $v_{2}, v_{5}, v_{4}$ & $v_{2}, v_{5}$ \\
\hline$v_{3}$ & $v_{1}, v_{2}, v_{3}$ & $v_{2}, v_{3}$ & - & $v_{3}, v_{2}, v_{5}, v_{4}$ & $v_{3}, v_{2}, v_{5}$ \\
\hline$v_{4}$ & $v_{1}, v_{4}$ & $v_{2}, v_{5}, v_{4}$ & $v_{3}, v_{2}, v_{5}, v_{4}$ & - & $v_{4}, v_{5}$ \\
\hline$v_{5}$ & $v_{1}, v_{2}, v_{5}$ & $v_{2}, v_{5}$ & $v_{3}, v_{2}, v_{5}$ & $v_{4}, v_{5}$ & - \\
\hline
\end{tabular}


Pewarnaan total pelangi suatu graf $G$ selalu dibutuhkan paling tidak $2(\operatorname{diam}(G))-1$ warna untuk mewarnai lintasan-lintasan setiap dua titik pada graf $G$. Oleh karena itu, diberikan proposisi berikut ini.

Proposisi 4 [3]. Misalkan $G$ graf terhubung tak trivial berdiameter diam $(G)$ maka $\operatorname{trc}(G) \geq$ $2(\operatorname{diam}(G))-1$.

\section{Bilangan Terhubung Total Pelangi pada Graf Sikat $\boldsymbol{B}_{\boldsymbol{n}}$ dan Graf Pembentuknya}

Pada bagian ini, dibahas mengenai bilangan terhubung total pelangi pada graf sikat yang dinotasikan $B_{n}$. Namun sebelumnya dibahas mengenai bilangan terhubung total pelangi pada graf pembentuk dari graf sikat, yaitu graf lintasan $P_{n}$ dan graf bintang $S_{n}$.

Teorema 5. Graf lintasan $P_{n}$ dengan $n$ titik dan $n-1$ sisi, $n \geq 2, n \in \mathbb{N}$. Bilangan terhubung total pelangi pada graf $P_{n}$ adalah $\operatorname{trc}\left(P_{n}\right)=2 n-3$.

Bukti. Dibentuk graf lintasan $P_{n}$ dimana $u_{i}, v_{j} \in V\left(P_{n}\right), i=1,2$ dan $j=1,2, \ldots, n-2$, yang kemudian dilakukan pewarnaan total pada lintasan di diameter $P_{n}$. Graf $P_{n}$ mempunyai $n$ titik dan $n-1$ sisi, dimana titik-titik tersebut adalah titik $u_{1}, u_{2}$, dan $v_{i}$ dengan $i=1,2, \ldots, n-2$. Graf $P_{n}$ mempunyai lintasan pada diameternya yaitu pada lintasan $u_{1}-u_{2}$ dimana semua titik $v_{i}$ merupakan titik internal pada lintasan tersebut dan graf $P_{n}$ merupakan graf terhubung. Akibatnya, banyak sisi pada graf $P_{n}$ juga merupakan diameternya. Jadi $\operatorname{diam}\left(P_{n}\right)=n-1$ dengan titik internal $P_{n}$ adalah $n-2$. Oleh karena itu, dengan menggunakan Proposisi 4 diperoleh:

$$
\begin{gathered}
\operatorname{trc}\left(P_{n}\right) \geq 2\left(\operatorname{diam}\left(P_{n}\right)\right)-1 \\
\operatorname{trc}\left(P_{n}\right) \geq 2(n-1)-1 \\
\operatorname{trc}\left(P_{n}\right) \geq 2 n-3
\end{gathered}
$$

Banyak warna yang dibutuhkan untuk mewarnai lintasan di diameter $P_{n}$ adalah $2 n-3$ warna. Sebanyak $2 n-3$ warna ini digunakan untuk mewarnai titik dan sisi yang lain, dengan setiap sisi dan titik pada graf $P_{n}$ mempunyai warna yang berbeda, kecuali titik $u_{1}$, titik $u_{2}$, dan titik $v_{1}$. Akan tetapi titik $u_{1}$ dan titik $u_{2}$ bukan merupakan titik internal pada lintasan dua titik manapun, akibatnya setiap dua titik pada graf $P_{n}$ mempunyai lintasan total pelangi. Lebih jelasnya, pewarnaan total tersebut dituliskan dalam bentuk fungsi pewarnaan total pelangi $c: V\left(P_{n}\right) \cup E\left(P_{n}\right) \rightarrow\{1,2, \ldots, 2 n-3\}$ dimana:

$$
\begin{array}{ll}
c\left(u_{i}\right)=1, & i=1,2 \\
c\left(v_{i}\right)=i, & i=1,2, \ldots, n-2 \\
c\left(v_{i} v_{i+1}\right)=i+n-1, & i=1,2, \ldots, n-3 \\
c\left(u_{1} v_{1}\right)=n-1 & \\
c\left(u_{2} v_{n-2}\right)=2 n-3 &
\end{array}
$$

Bilangan terbesar yang dipetakan oleh fungsi $c$ adalah $2 n-3$. Sehingga dari konstruksi pewarnaan total pelangi $c$ diperoleh $\operatorname{trc}\left(P_{n}\right) \leq 2 n-3$.

Oleh karena $\operatorname{trc}\left(P_{n}\right) \geq 2 n-3$ dan $\operatorname{trc}\left(P_{n}\right) \leq 2 n-3$, maka terbukti bahwa $\operatorname{trc}\left(P_{n}\right)=2 n-3$.

Sebagai ilustrasi, diberikan graf lintasan $P_{n}$ untuk $n=2,3,4,5$ dengan pewarnaan total pelangi.

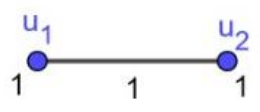

(a)

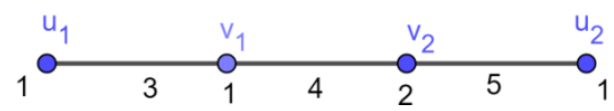

(c)

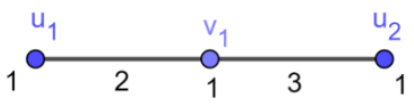

(b)

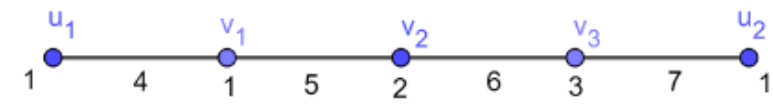

(d)

Gambar 3. (a) Graf $P_{2}$, (b) Graf $P_{3}$, (c) Graf $P_{4}$, (d) Graf $P_{5}$ 
Berdasarkan Gambar 3(a), diperoleh bahwa setiap dua titik pada graf $P_{2}$ memiliki lintasan total pelangi dan jumlah warna yang diperlukan untuk mewarnai $P_{2}$ sebanyak 1 warna, oleh karena itu $\operatorname{trc}\left(P_{2}\right)=1$. Begitu juga graf $P_{3}$ pada Gambar 3(b), graf $P_{4}$ pada Gambar 3(c), dan graf $P_{5}$ pada Gambar 3(d), dimana setiap dua pasang titik pada graf-graf tersebut mempunyai lintasan total pelangi, dan diperoleh $\operatorname{trc}\left(P_{3}\right)=3, \operatorname{trc}\left(P_{4}\right)=5$, dan $\operatorname{trc}\left(P_{5}\right)=7$.

Teorema 6. Misalkan $G$ adalah graf bintang $S_{n}$ dengan $n+1$ titik dan $n$ sisi, $n \in \mathbb{N}$. Bilangan terhubung total pelangi pada graf bintang $S_{n}$ adalah

$$
\operatorname{trc}\left(S_{n}\right)= \begin{cases}1, & \text { jika } n=1 \\ n+1, & \text { jika } n \geq 2\end{cases}
$$

Bukti. Dibentuk graf bintang $S_{n}$ dimana $u, v_{i} \in V\left(S_{n}\right), i=1,2, \ldots, n$, yang kemudian dilakukan pewarnaan total pada lintasan di diameter $S_{n}$, dimana $\operatorname{diam}\left(S_{n}\right)=2$ dengan titik internal dari diameter tersebut adalah 1 . Oleh karena itu, warna yang diperlukan untuk mewarnai lintasan pada diameter graf $S_{n}$ adalah sebanyak 3 warna. Artinya, paling tidak sebanyak 3 warna untuk mewarnai sisi dan titik lainnya. Setelah itu, diwarnai sisi maupun titik yang lain, dengan setiap sisi pada graf $S_{n}$ memiliki warna yang berbeda, sedangkan semua titik $S_{n}$ berwarna sama. Titik $u$ bertetangga dengan semua titik $v_{i}$ dengan $i=1,2, \ldots, n$. Oleh karena itu, setiap lintasan $u-v_{i}$ jelas mempunyai lintasan total pelangi. Setiap lintasan $v_{i}-v_{j}$ dengan $i \neq j$ hanya mempunyai titik $u$ sebagai titik internal, akibatnya setiap lintasan $v_{i}-v_{j}$ juga mempunyai lintasan total pelangi. Lebih jelasnya, pewarnaan total tersebut dituliskan dalam bentuk fungsi pewarnaan total pelangi $c: V\left(S_{n}\right) \cup E\left(S_{n}\right) \rightarrow$ $\{1,2, \ldots, n+1\}$ dimana:

$$
\begin{array}{ll}
c(u)=1 & \\
c\left(v_{i}\right)=1, & i=1,2, \ldots, n \\
c\left(u v_{i}\right)=i+1, & i=1,2, \ldots, n
\end{array}
$$

(i) Kasus 1, untuk $n=1$

Pada Teorema 5 telah dibuktikan bahwa $\operatorname{trc}\left(P_{n}\right)=2 n-3$, akibatnya $\operatorname{trc}\left(P_{2}\right)=1$. Graf $S_{1}$ sama dengan graf $P_{2}$, maka $\operatorname{trc}\left(S_{1}\right)=1$.

(ii) Kasus 2, untuk $n \geq 2$

Bilangan terbesar yang dipetakan oleh fungsi $c$ adalah $n+1$. Sehingga dari konstruksi pewarnaan total pelangi $c$ diperoleh $\operatorname{trc}\left(S_{n}\right) \leq n+1$.

Pada kasus 2, yaitu untuk $n \geq 2$, yang dibuktikan adalah $\operatorname{trc}\left(S_{n}\right)=n+1$, dan dari fungsi $c$ diperoleh bahwa $\operatorname{trc}\left(S_{n}\right) \leq n+1$. Oleh karena itu, yang dibuktikan selanjutnya adalah $\operatorname{trc}\left(S_{n}\right) \nless$ $n+1$ dengan menggunakan pembuktian kontradiksi.

Andaikan $\operatorname{trc}\left(S_{n}\right)<n+1$. Ambil sebanyak $n$ warna atau $\operatorname{trc}\left(S_{n}\right)=n$. Pada graf $S_{n}$, setiap lintasan dua titik, paling banyak memiliki 1 titik internal, yaitu titik $u$, sehingga warna yang diperlukan untuk mewarnai semua titik pada graf bintang $S_{n}$ adalah sebanyak 1 warna dengan warna titik $v_{i}$ dimana $i=1,2, \ldots, n$ mempunyai warna yang sama dengan titik $u$. Oleh karena $\operatorname{trc}\left(S_{n}\right)=n$, maka tersisa $n-1$ warna untuk mewarnai sisi-sisi pada graf bintang $S_{n}$. Banyak sisi pada graf bintang $S_{n}$ adalah sebanyak $n$, akibatnya ada satu 1 sisi yang memiliki warna yang sama dengan sisi yang lain. Misalkan terdapat $c\left(v_{i} u\right)=c\left(v_{j} u\right), i \neq j$ dengan $c$ merupakan fungsi pewarnaan total pelangi. Setiap lintasan dua titik pada $S_{n}$ hanya mempunyai satu lintasan, akibatnya lintasan $v_{i}-v_{j}$ yaitu $v_{i}, u, v_{j}$ tidak mempunyai lintasan total pelangi. Oleh karena itu, pengandaian $\operatorname{trc}\left(S_{n}\right)=n$ kontradiksi dengan definisi terhubung total pelangi. Sehingga terbukti bahwa $\operatorname{trc}\left(S_{n}\right) \nless n+1$. Akibatnya, dikarenakan $\operatorname{trc}\left(S_{n}\right) \leq n+1$ dan diperoleh $\operatorname{trc}\left(S_{n}\right) \nless n+1$, maka $\operatorname{trc}\left(S_{n}\right)=n+1$.

Jadi terbukti bahwa $\operatorname{trc}\left(S_{n}\right)= \begin{cases}1, & n=1 \\ n+1, & n \geq 2\end{cases}$ 
Sebagai ilustrasi, diberikan graf bintang $S_{n}$ untuk $n=2,3,4,5$ dengan pewarnaan total pelangi.

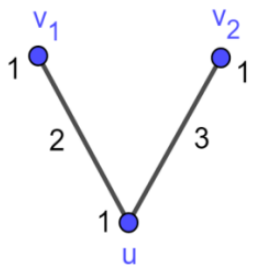

(a)

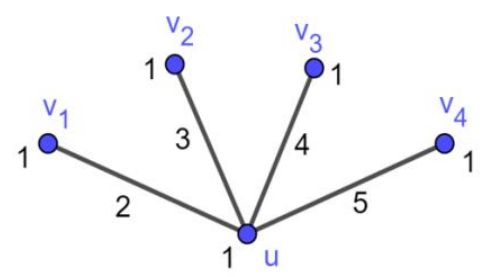

(c)

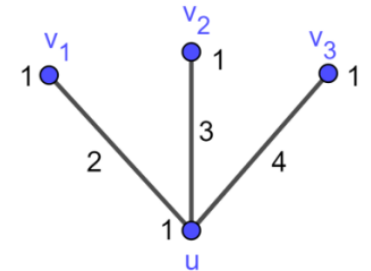

(b)

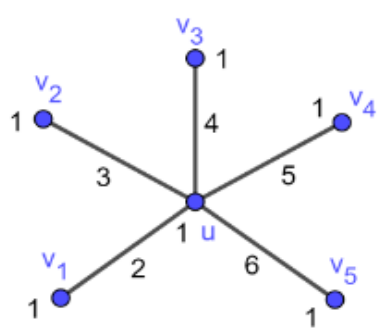

(d)

Gambar 4. (a) Graf $S_{2}$, (b) Graf $S_{3}$, (c) Graf $S_{4}$, dan (d) Graf $S_{5}$

Berdasarkan Gambar 4(a), diperoleh bahwa setiap dua titik pada graf $S_{2}$ memiliki lintasan total pelangi dan jumlah warna yang diperlukan untuk mewarnai $S_{2}$ sebanyak 3 warna, oleh karena itu $\operatorname{trc}\left(S_{2}\right)=3$. Begitu juga graf $S_{3}$ pada Gambar 4(b), graf $S_{4}$ pada Gambar 4(c), dan graf $S_{5}$ pada Gambar 4(d), dimana setiap dua pasang titik pada graf-graf tersebut mempunyai lintasan total pelangi, dan diperoleh $\operatorname{trc}\left(S_{3}\right)=4, \operatorname{trc}\left(S_{4}\right)=5$, dan $\operatorname{trc}\left(S_{5}\right)=6$.

Teorema 7. Graf sikat $B_{n}$ dengan $2 n$ titik dan $2 n-1$ sisi, $n \geq 2, n \in \mathbb{N}$. Bilangan terhubung total pelangi pada graf sikat $B_{n}$ adalah $\operatorname{trc}\left(B_{n}\right)=3 n-1$.

Bukti. Dibentuk graf sikat $B_{n}$ dimana $u_{i}, v_{i} \in V\left(B_{n}\right), i=1,2, \ldots, n$, yang kemudian dilakukan pewarnaan total pada lintasan di diameter $B_{n}$, dimana diam $\left(B_{n}\right)=n+1$ dengan titik internal dari lintasan di diameter tersebut adalah $n$. Oleh karena itu, warna yang diperlukan untuk mewarnai lintasan pada diameter graf $B_{n}$ adalah sebanyak $2 n+1$ warna. Artinya, paling tidak sebanyak $2 n+1$ warna untuk mewarnai sisi dan titik lainnya. Setelah itu, diwarnai sisi maupun titik yang lain, dengan semua sisi dan titik diberi warna yang berbeda satu sama lain, kecuali titik $u_{i}$ dengan $i=1,2, \ldots, n$ yang diberi warna yang sama dengan titik $v_{1}$. Oleh karena titik $u_{i}$ bukan merupakan titik internal pada lintasan dua titik manapun, maka setiap pasang titik di $B_{n}$ mempunyai lintasan total pelangi. Lebih jelasnya, pewarnaan total tersebut dituliskan dalam bentuk fungsi pewarnaan total pelangi $c: V\left(B_{n}\right) \cup$ $E\left(B_{n}\right) \rightarrow\{1,2, \ldots, 3 n-1\}$ dimana:

$$
\begin{array}{ll}
c\left(u_{i}\right)=1, & i=1,2, \ldots, n \\
c\left(v_{i}\right)=i, & i=1,2, \ldots, n \\
c\left(u_{i} v_{i}\right)=2 n+i-1, & i=1,2, \ldots, n \\
c\left(v_{i} v_{i+1}\right)=i+n, & i=1,2, \ldots, n-1
\end{array}
$$

Bilangan terbesar yang dipetakan oleh fungsi $c$ adalah $3 n-1$. Sehingga dari konstruksi pewarnaan total pelangi $c$ diperoleh $\operatorname{trc}\left(B_{n}\right) \leq 3 n-1$.

Pada Teorema 7 yang dibuktikan adalah $\operatorname{trc}\left(B_{n}\right)=3 n-1$, dan dari fungsi $c$ diperoleh $\operatorname{trc}\left(B_{n}\right) \leq$ $3 n-1$. Oleh karena itu, yang dibuktikan selanjutnya adalah $\operatorname{trc}\left(B_{n}\right) \nless 3 n-1$ dengan menggunakan pembuktian kontradiksi.

Andaikan $\operatorname{trc}\left(B_{n}\right)<3 n-1$. Ambil sebanyak $3 n-2$ warna atau $\operatorname{trc}\left(B_{n}\right)=3 n-2$. Titik $u_{i}$ dengan $i=1,2, \ldots, n$ bukan merupakan titik internal untuk lintasan setiap dua titik yang berbeda, akibatnya semua titik $u_{i}$ dapat diberi warna yang sama satu sama lain. Sehingga warna yang 
dibutuhkan untuk mewarnai titik $u_{i}$ adalah 1 . Setiap titik $v_{i}$ merupakan titik yang berada pada diameter $B_{n}$, jadi perlu penambahan $n-1$ warna lagi untuk mewarnai titik $v_{i}$, sedangkan 1 titik $v_{i}$ yang belum terwarnai bisa diberi warna yang sama dengan titik yang bukan merupakan titik internal, yaitu titik $u_{i}$. Jadi warna yang diperlukan untuk mewarnai semua titik pada graf Sikat $B_{n}$ adalah sebanyak $n$ warna. Oleh karena $\operatorname{trc}\left(B_{n}\right)=3 n-2$, maka tersisa $3 n-2-n=2 n-2$ warna untuk mewarnai sisi-sisi pada graf sikat $B_{n}$, padahal banyak sisi pada graf sikat $B_{n}$ adalah sebanyak $2 n-1$. Akibatnya ada satu sisi yang akan memiliki warna yang sama dengan sisi yang lain. Misalkan $c\left(u_{i} v_{i}\right)=c\left(u_{j} v_{j}\right)$ dan $c$ merupakan fungsi pewarnaan total pelangi, dengan $B_{n}$ memiliki suatu lintasan $u_{i}-u_{j}$. Setiap lintasan dua titik pada $B_{n}$ hanya mempunyai satu lintasan, akibatnya lintasan $u_{i}-v_{j}$ yaitu $u_{i}, v_{i}, \ldots, v_{j}, u_{j}$ tidak mempunyai lintasan total pelangi. Begitu pula jika $c\left(u_{i} v_{i}\right)=$ $c\left(v_{j-1} v_{j}\right)$, maka lintasan $u_{i}, v_{i}, \ldots, v_{j-1}, v_{j}$ tidak mempunyai lintasan total pelangi. Ataupun jika $c\left(v_{i} v_{i+1}\right)=c\left(v_{j-1} v_{j}\right)$, maka lintasan $v_{i}, v_{i+1}, \ldots, v_{j-1}, v_{j}$ tidak mempunyai lintasan total pelangi. Oleh karena itu, pengandaian $\operatorname{trc}\left(B_{n}\right)=3 n-2$ kontradiksi dengan definisi terhubung total pelangi. Sehingga terbukti bahwa $\operatorname{trc}\left(B_{n}\right) \nless 3 n-1$. Akibatnya, dikarenakan $\operatorname{trc}\left(B_{n}\right) \leq 3 n-1$ dan diperoleh $\operatorname{trc}\left(B_{n}\right) \nless 3 n-1$, maka $\operatorname{trc}\left(B_{n}\right)=3 n-1$.

Sebagai ilustrasi, diberikan graf sikat $B_{n}$ untuk $n=2,3,4,5$ dengan pewarnaan total pelangi.

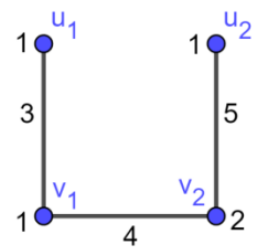

(a)

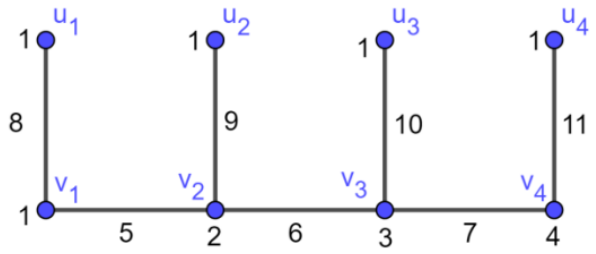

(c)

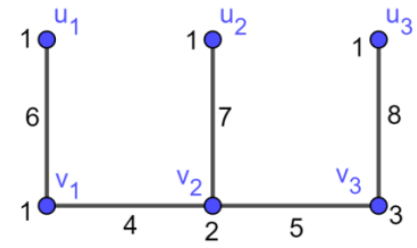

(b)

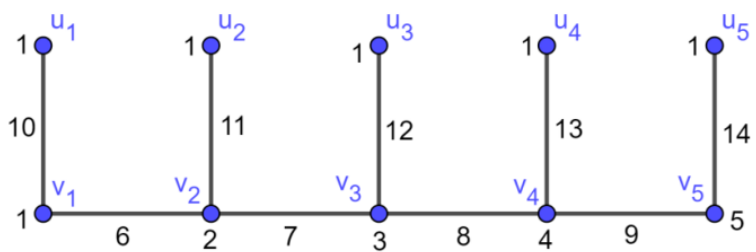

(d)

Gambar 5. (a) Graf $B_{2}$, (b) Graf $B_{3}$, (c) Graf $B_{4}$, dan (d) Graf $B_{5}$

Berdasarkan Gambar 5(a), diperoleh bahwa setiap dua titik pada graf $B_{2}$ memiliki lintasan total pelangi dan jumlah warna yang diperlukan untuk mewarnai $B_{2}$ sebanyak 5 warna, oleh karena itu $\operatorname{trc}\left(B_{2}\right)=5$. Begitu juga graf $B_{3}$ pada Gambar 5(b), graf $B_{4}$ pada Gambar 5(c), dan graf $B_{5}$ pada Gambar 5(d), dimana setiap dua pasang titik pada graf-graf tersebut mempunyai lintasan total pelangi, dan diperoleh $\operatorname{trc}\left(B_{3}\right)=8, \operatorname{trc}\left(B_{4}\right)=11$, dan $\operatorname{trc}\left(B_{5}\right)=14$.

\section{Bilangan Terhubung Total Pelangi pada Graf Garis dari Graf Sikat $L\left(B_{n}\right)$}

Pada bagian ini, dibahas mengenai bilangan terhubung total pelangi pada graf garis dari graf sikat yang dinotasikan $L\left(B_{n}\right)$.

Definisi 8 [5]. Graf garis pada suatu graf $G$ dinotasikan dengan $L(G)$ merupakan graf dengan himpunan titik-titiknya adalah $E(G)$, dimana dua titiknya bertetangga jika dan hanya jika sisi yang bersesuaian bertetangga di $G$.

Teorema 9. Graf garis dari graf sikat $B_{n}$ yang dinotasikan $L\left(B_{n}\right)$ memiliki bilangan terhubung total pelangi yaitu trc $L\left(B_{n}\right)=2 n-1$.

Bukti. Dibentuk graf garis dari graf sikat $L\left(B_{n}\right)$ dimana $u_{i}, v_{j} \in V\left(L\left(B_{n}\right)\right), i=1,2, \ldots, n$, dan $j=1,2, \ldots, n-1$, yang kemudian dilakukan pewarnaan total pada lintasan di diameter $L\left(B_{n}\right)$. Diameter dari graf $L\left(B_{n}\right)$ adalah panjang lintasan $u_{1}, v_{1}, v_{2}, \ldots, v_{n-1}, u_{n}$, yang berarti ada sebanyak 
$n+1$ titik dengan titik internal sebanyak $n-1$ dan $n$ sisi pada lintasan di diameter $L\left(B_{n}\right)$, akibatnya $\operatorname{diam} L\left(B_{n}\right)=n$. Dengan menggunakan Proposisi 4 diperoleh $\operatorname{trc} L\left(B_{n}\right) \geq 2 n-1$.

Oleh karena diam $L\left(B_{n}\right)=n$ dan titik internal pada lintasan di diameter $L\left(B_{n}\right)$ adalah $n-1$, maka sebanyak $2 n-1$ warna untuk mewarnai diameter $L\left(B_{n}\right)$. Sehingga sebanyak $2 n-1$ warna itu juga digunakan untuk mewarnai titik dan sisi lainnya, sehingga titik $u_{i}-u_{j}$ untuk $i \neq j$ mempunyai lintasan total pelangi pada lintasan $u_{i}, v_{i}, v_{i+1}, \ldots, v_{j-1}, u_{j}$. Setiap titik $v_{k}$ dengan $k=1,2, \ldots, n-1$ merupakan titik internal pada lintasan $u_{i}-u_{j}$, akibatnya setiap lintasan $v_{i}-v_{j}$ juga mempunyai lintasan total pelangi. Lebih jelasnya, pewarnaan total tersebut dituliskan dalam bentuk fungsi pewarnaan total pelangi $c: V\left(L\left(B_{n}\right)\right) \cup E\left(L\left(B_{n}\right)\right) \rightarrow\{1,2, \ldots, 2 n-1\}$ dimana:

$$
\begin{array}{ll}
c\left(u_{i}\right)=1, & i=1,2, \ldots, n \\
c\left(v_{i}\right)=i, & i=1,2, \ldots, n-1 \\
c\left(u_{i} v_{i}\right)=n, & i=1,2, \ldots, n-1 \\
c\left(u_{i+1} v_{i}\right)=2 n-1, & i=1,2, \ldots, n-1 \\
c\left(v_{i} v_{i+1}\right)=i+n, & i=1,2, \ldots, n-2
\end{array}
$$

Bilangan terbesar yang dipetakan oleh fungsi $c$ adalah $2 n-1$. Sehingga dari konstruksi pewarnaan total pelangi $c$ diperoleh $\operatorname{trc} L\left(B_{n}\right) \leq 2 n-1$.

Oleh karena $\operatorname{trc} L\left(B_{n}\right) \geq 2 n-1$ dan $\operatorname{trc} L\left(B_{n}\right) \leq 2 n-1$, maka bilangan terhubung total yang memenuhi adalah $\operatorname{trc} L\left(B_{n}\right)=2 n-1$.

Sebagai ilustrasi, diberikan graf garis dari graf sikat $L\left(B_{n}\right)$ untuk $n=2,3,4,5$ dengan pewarnaan total pelangi.

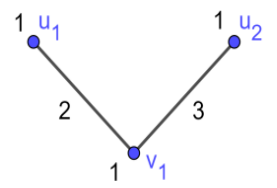

(a)

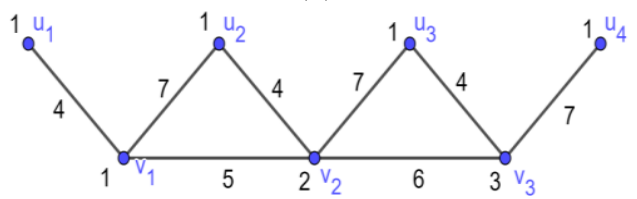

(c)

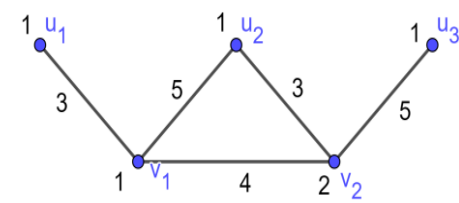

(b)

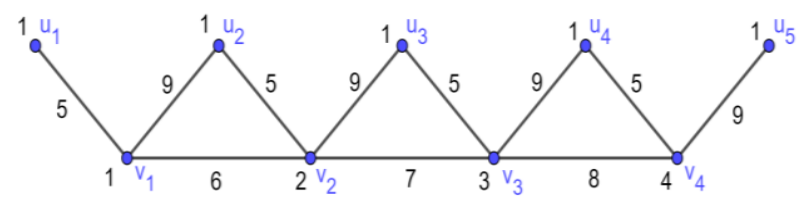

(d)

Gambar 6. (a) Graf $L\left(B_{2}\right)$, (b) Graf $L\left(B_{3}\right)$, (c) Graf $L\left(B_{4}\right)$, dan (d) Graf $L\left(B_{5}\right)$

Berdasarkan Gambar 6(a), diperoleh bahwa setiap dua titik pada graf $L\left(B_{2}\right)$ memiliki lintasan total pelangi dan jumlah warna yang diperlukan untuk mewarnai $L\left(B_{2}\right)$ sebanyak 3 warna, oleh karena itu $\operatorname{trc} L\left(B_{2}\right)=3$. Begitu juga graf $L\left(B_{3}\right)$ pada Gambar 6(b), graf $L\left(B_{4}\right)$ pada Gambar 6(c), dan graf $L\left(B_{5}\right)$ pada Gambar $6(\mathrm{~d})$, dimana setiap dua pasang titik pada graf-graf tersebut mempunyai lintasan total pelangi, dan diperoleh $\operatorname{trc} L\left(B_{3}\right)=5, \operatorname{trc} L\left(B_{4}\right)=7$, dan $\operatorname{trc} L\left(B_{5}\right)=9$.

\section{Bilangan Terhubung Total Pelangi pada Double Graf Garis dari Graf Sikat $D\left(L\left(B_{n}\right)\right)$}

Pada bagian ini, dibahas mengenai bilangan terhubung total pelangi pada double graf garis dari graf sikat yang dinotasikan $D\left(L\left(B_{n}\right)\right)$.

Definisi 10 [6]. Double graf garis dari graf sikat dinotasikan dengan $D\left(L\left(B_{n}\right)\right)$ yang terdiri dari dua graf garis dari graf sikat yang mempunyai sebuah lintasan yang sama.

Teorema 11. Double graf garis dari graf sikat $B_{n}$ yang dinotasikan $D\left(L\left(B_{n}\right)\right)$ memiliki bilangan terhubung total pelangi, yaitu $\operatorname{trc} D\left(L\left(B_{n}\right)\right)=2 n+1$.

Bukti. Dibentuk graf garis dari graf sikat dengan $u_{i}, v_{j}, w_{k} \in V\left(D\left(L\left(B_{n}\right)\right)\right)$ dengan $i=1,2, \ldots, n-$ $1 ; j=1,2, \ldots, n ; k=1,2, \ldots, n$, yang kemudian dilakukan pewarnaan total pada lintasan di diameter 
$D\left(L\left(B_{n}\right)\right)$, dimana diam $D\left(L\left(B_{n}\right)\right)=n$ dengan titik internal dari lintasan di diameter tersebut adalah $n-1$. Oleh karena itu, warna yang diperlukan untuk mewarnai lintasan pada diameter graf $D\left(L\left(B_{n}\right)\right)$ adalah sebanyak $2 n-1$ warna. Artinya, paling tidak sebanyak $2 n-1$ warna untuk mewarnai sisi dan titik lainnya, dengan titik $v_{i}-v_{j}$ untuk $i \neq j$ memiliki lintasan total pelangi yaitu pada lintasan $v_{i}, u_{i}, u_{i+1}, \ldots, u_{j-1}, v_{j}$, dan titik $w_{i}-w_{j}$ untuk $i \neq j$ memiliki lintasan total pelangi yaitu pada lintasan $w_{i}, u_{i}, u_{i+1}, \ldots, u_{j-1}, w_{j}$, serta titik $w_{i}-v_{j}$ untuk $i \neq j$ memiliki lintasan total pelangi yaitu pada lintasan $w_{i}, u_{i}, u_{i+1}, \ldots, u_{j-1}, v_{j}$. Oleh karena itu, setiap titik $u_{i}$ ke $u_{j}$ juga memiliki lintasan total pelangi. Artinya setiap pasang titik di $D\left(L\left(B_{n}\right)\right)$ mempunyai lintasan total pelangi. Lebih jelasnya, pewarnaan total tersebut dituliskan dalam bentuk fungsi pewarnaan total pelangi $c: V\left(D\left(L\left(B_{n}\right)\right)\right) \cup$ $E\left(D\left(L\left(B_{n}\right)\right)\right) \rightarrow\{1,2, \ldots, 2 n+1\}$ dimana:

$$
\begin{array}{ll}
c\left(u_{i}\right)=i, & i=1,2, \ldots, n-1 \\
c\left(v_{i}\right)=c\left(w_{i}\right)=1, & i=1,2, \ldots, n \\
c\left(u_{i} u_{i+1}\right)=i+n, & i=1,2, \ldots, n-2 \\
c\left(u_{i} v_{i}\right)=2 n, & i=1,2, \ldots, n-1 \\
c\left(u_{i} v_{i+1}\right)=2 n+1, & i=1,2, \ldots, n-1 \\
c\left(u_{i} w_{i}\right)=n, & i=1,2, \ldots, n-1 \\
c\left(v_{i} w_{i+1}\right)=2 n-1, & i=1,2, \ldots, n-1
\end{array}
$$

Bilangan terbesar yang dipetakan oleh fungsi $c$ adalah $2 n+1$. Sehingga dari konstruksi pewarnaan total pelangi $c$ diperoleh $\operatorname{trc} D\left(L\left(B_{n}\right)\right) \leq 2 n+1$.

Pada Teorema 11 yang dibuktikan adalah $\operatorname{trc} D\left(L\left(B_{n}\right)\right)=2 n+1$, dan dari fungsi $c$ diperoleh $\operatorname{trc} D\left(L\left(B_{n}\right)\right) \leq 2 n+1$. Oleh karena itu, yang dibuktikan selanjutnya adalah $\operatorname{trc} D\left(L\left(B_{n}\right)\right) \nless 2 n+$ 1 dengan menggunakan pembuktian kontradiksi.

Andaikan $\operatorname{trc} D\left(L\left(B_{n}\right)\right)<2 n+1$. Ambil sebanyak $2 n$ warna atau $\operatorname{trc} D\left(L\left(B_{n}\right)\right)=2 n$. Graf $D\left(L\left(B_{n}\right)\right)$ mempunyai diameter sebanyak $n$, oleh karena itu setidaknya perlu $n-1$ warna untuk mewarnai titik dari $w_{1}$ ke $w_{n}$ atau dari $v_{1}$ ke $v_{n}$ yang sama-sama merupakan diameter dari $D\left(L\left(B_{n}\right)\right)$. Pada konstruksi pewarnaan titik diperoleh warna yang perlukan untuk mewarnai semua titik pada $D\left(L\left(B_{n}\right)\right)$ sebanyak $n-1$ warna juga. Sehingga jumlah warna untuk mewarnai semua titik pada graf $D\left(L\left(B_{n}\right)\right)$ cukup dengan $n-1$ warna saja. Oleh karena $\operatorname{trc} D\left(L\left(B_{n}\right)\right)=2 n$, maka warna yang tersisa setelah diwarnai semua titik pada $D\left(L\left(B_{n}\right)\right)$ adalah sebanyak $2 n-(n-1)=n+1$ warna, dan sisa warna tersebut digunakan untuk mewarnai diameternya yaitu dari titik $w_{1}$ ke $w_{n}$ atau dari $v_{1}$ ke $v_{n}$. Setelah diwarnai diameternya, maka warna yang tersisa adalah 1 warna. Pada $D\left(L\left(B_{n}\right)\right)$, lintasan dari titik $w_{1}$ dan $v_{1}$ ke titik lainnya harus melewai titik $u_{1}$ dan lintasan dari titik $w_{n}$ dan $v_{n}$ ke titik lainnya harus melewati titik $u_{n-1}$, akibatnya diperlukan 4 warna yang berbeda untuk mewarnai sisi $\left(u_{1} w_{1}\right)$, sisi $\left(u_{1} v_{1}\right)$, sisi $\left(u_{n-1} w_{n}\right)$, dan sisi $\left(u_{n-1} v_{1}\right)$. Jika diameter yang diwarnai sebelumnya adalah dari titik $w_{1}$ ke $w_{n}$, maka hanya perlu 2 warna berbeda yang digunakan untuk mewarnai sisi $\left(u_{1} v_{1}\right)$ dan sisi $\left(u_{n-1} v_{1}\right)$ karena sisi $\left(u_{1} w_{1}\right)$ dan sisi $\left(u_{n-1} w_{n}\right)$ sudah terwarnai dengan warna yang berbeda. Akan tetapi warna yang tersisa hanyalah 1 warna, akibatnya satu diantara sisi $\left(u_{1} v_{1}\right)$ dan sisi $\left(u_{n-1} v_{1}\right)$ akan memiliki warna yang sama dengan sisi lainnya. Sehingga akan ada lintasan dari $w_{1}-v_{n}$ yaitu $w_{1}, u_{1}, \ldots, u_{n-1}, v_{n}$ atau $w_{n}-v_{1}$ yaitu $w_{n}, u_{n-1}, \ldots, u_{1}, v_{1}$ yang tidak memiliki lintasan total pelangi, yang berarti pengandaian $\operatorname{trc} D\left(L\left(B_{n}\right)\right)=2 n$ kontradiksi dengan definisi terhubung total pelangi. Sehingga terbukti bahwa $\operatorname{trc} D\left(L\left(B_{n}\right)\right) \nless 2 n+1$. Akibatnya, dikarenakan $\operatorname{trc} D\left(L\left(B_{n}\right)\right) \leq 2 n+1$ dan diperoleh $\operatorname{trc} D\left(L\left(B_{n}\right)\right) \nless 2 n+1$, maka $\operatorname{trc} D\left(L\left(B_{n}\right)\right)=2 n+1$. 
Sebagai ilustrasi, diberikan double graf garis dari graf sikat $D\left(L\left(B_{n}\right)\right)$ untuk $n=2,3,4,5$ dengan pewarnaan total pelangi.

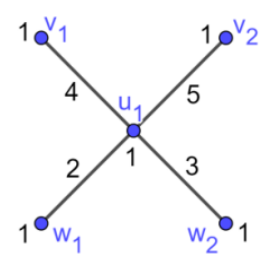

(a)

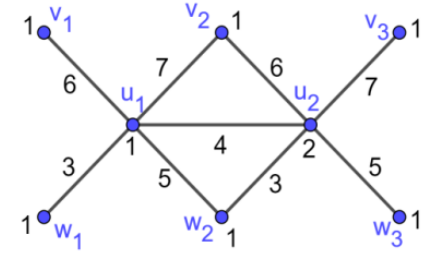

(b)

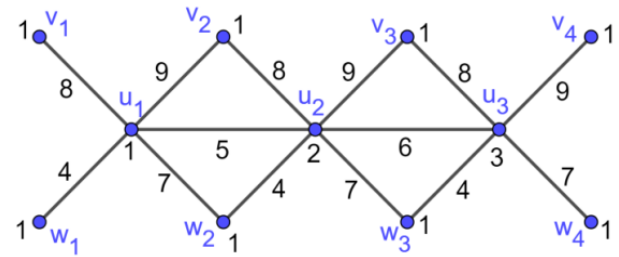

(c)

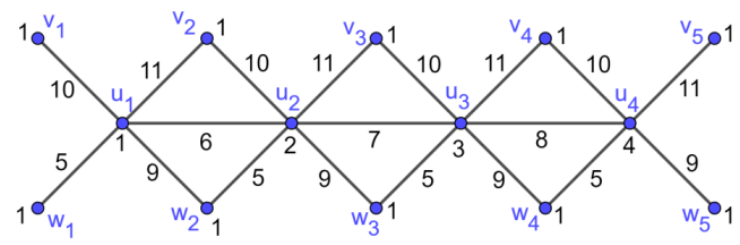

(d)

Gambar 7. (a) Graf $D\left(L\left(B_{2}\right)\right)$, (b) Graf $D\left(L\left(B_{3}\right)\right)$, (c) Graf $D\left(L\left(B_{4}\right)\right)$, dan (d) Graf $D\left(L\left(B_{5}\right)\right)$

Berdasarkan Gambar 7(a), diperoleh bahwa setiap dua titik pada graf $D\left(L\left(B_{2}\right)\right)$ memiliki lintasan total pelangi dan jumlah warna yang diperlukan untuk mewarnai $D\left(L\left(B_{2}\right)\right)$ sebanyak 5 warna, oleh karena itu $\operatorname{trc} D\left(L\left(B_{2}\right)\right)=5$. Begitu juga graf $D\left(L\left(B_{3}\right)\right)$ pada Gambar 7(b), graf $D\left(L\left(B_{4}\right)\right)$ pada Gambar $7(\mathrm{c})$, dan graf $D\left(L\left(B_{5}\right)\right)$ pada Gambar $7(\mathrm{~d})$, dimana setiap dua pasang titik pada graf-graf tersebut mempunyai lintasan total pelangi, dan diperoleh $\operatorname{trc} D\left(L\left(B_{3}\right)\right)=7, \operatorname{trc} D\left(L\left(B_{4}\right)\right)=8$, dan $\operatorname{trc} D\left(L\left(B_{5}\right)\right)=11$.

\section{KESIMPULAN}

Bilangan terhubung total pelangi suatu graf $G$ dinotasikan $\operatorname{trc}(G)$ merupakan jumlah warna minimal yang digunakan sehingga graf $G$ bersifat terhubung total pelangi. Nilai $\operatorname{trc}(G)$ dapat ditentukan dengan mewarnai semua sisi dan titik pada graf $G$ dengan jumlah warna seminimal mungkin, dimana dengan pewarnaan yang dilakukan membuat setiap pasang titik di $G$ memiliki lintasan total pelangi. Berdasarkan penelitian yang dilakukan, diperoleh bahwa bilangan terhubung total pelangi pada graf garis dan double graf garis dari graf sikat beserta graf pembentuknya adalah sebagai berikut:

1. Bilangan terhubung pelangi pada graf lintasan adalah $\operatorname{trc}\left(P_{n}\right)=2 n-3$.

2. Bilangan terhubung total pelangi pada graf bintang adalah $\operatorname{trc}\left(S_{n}\right)=1$ untuk $n=1$ dan $\operatorname{trc}\left(S_{n}\right)=n+1$ untuk $n \geq 2$.

3. Bilangan terhubung total pelangi pada graf sikat adalah $\operatorname{trc}\left(B_{n}\right)=3 n-1$.

4. Bilangan terhubung total pelangi pada graf garis dari graf sikat adalah $\operatorname{trc} L\left(B_{n}\right)=2 n-1$.

5. Bilangan terhubung total pelangi pada double graf garis dari graf sikat adalah $\operatorname{trc} D\left(L\left(B_{n}\right)\right)=$ $2 n+1$.

\section{DAFTAR PUSTAKA}

[1]. Chartrand G, Kalamazoo, Garry LJ, Valley S. Rainbow Connection in Graphs. Mathematica Bohemica.2008; 133:85-98.

[2]. Krivelevich M, Yuster R. The Rainbow Connection of a Graph Is (at Most) Reciprocal to Its Minimum Degree. Journal of Graph Theory.2009;185-191.

[3]. Liu H, Mestre A, Sousa T. Total Rainbow $k$-Connection in Graphs. Discrete Applied Mathematics.2014; 174:92-101.

[4]. Chartrand G dan Lesniak L. Graphs and Digraph. Bota Raton: Chapman and Hall; 1996. 
[5]. Sun Y. On Rainbow Total-Coloring of a Graph. Discrete Applied Mathematics.2015; 194:171177.

[6]. Alatif M, Rangaiah P, Nayaka SR. Boundary Domination of Line and Middle Graph of Wheel Graph Families. International Journal of Computer Applications.2016; 134:1-5.

[7]. Sandhya SS, Merly EER, Kavitha S. Super Stolarky-3 Mean Labeling of Quadrilateral Snake Graphs. International Journal of Computational and Applied Mathematics.2018; 13:1-7.

$\begin{array}{ll}\text { DOROTEA RAHMAWATI } & \begin{array}{c}\text { : Jurusan Matematika FMIPA UNTAN, Pontianak, } \\ \text { dorotearahmawati3@ gmail.com } \\ \text { : Jurusan Matematika FMIPA UNTAN, Pontianak, } \\ \text { helmi@math.untan.ac.id }\end{array} \\ \text { HELMI } & \begin{array}{c}\text { : Jurusan Matematika FMIPA UNTAN, Pontianak, } \\ \text { fransiskusfran@math.untan.ac.id }\end{array}\end{array}$

